\title{
Formulation and Evaluation of Wound Healing Effect of Aqueous Herbal Cream Containing Various Extracts of Passiflora foetida Linn., Leaves
}

\author{
Akila E*1, C. Geetha Priya ${ }^{1}$
}

${ }^{*}$ Assistant Professor, Department of Pharmacognosy, RR College of Pharmacy, Bangalore, Karnataka, India

${ }^{2}$ Department of Pharmaceutical Chemistry, RR College of Pharmacy, Bangalore, Karnataka, India

\begin{abstract}
Wounds are a major cause of concern for the patient and clinician alike; chronic Wounds affect a large number of patients and seriously reduce their quality of life. Wound healing is the process of repair that follows injury to the skin and other soft tissues. A cream is a preparation of a medication for topical use that contains a water base. Essentially, it is a preparation of oil in water. Herbal remedies used in folk medicine provide an interesting and still largely unexplored source for the creation and development of potentially new drugs, which might help to overcome the growing problem of resistance and also the toxicity of the currently available commercial antibiotics. In this study we have formulated an Aqueous herbal cream satisfying almost all pharmaceutical parameters which shows better wound healing activity. The wound healing of effect of Aqueous Herbal cream of various extracts of leaves of Passiflora foetida L. was evaluated by incision and excision wound model. The experimental results and histopathological studies showed that Aqueous Herbal Cream of Passiflora foetida L. leaves exhibits significant wound healing property as compared to control group of animals.
\end{abstract}

Keywords : Herbal Cream, Passiflora foetida, Incision wound, Histopathology.

\section{INTRODUCTION}

Wounds are a major cause of concern for the patient and clinician alike; chronic wounds affect a large number of patients and seriously reduce their quality of life. Current estimates indicate that nearly 6 million people suffer from chronic wounds worldwide. The prevalence of chronic wounds in the community has been reported as 4.5 per 1000 population, whereas in the case of acute wounds, it is 10.5 per 1000 population. Nearly $1-3 \%$ of the drugs listed in Western pharmacopoeia are intended for use in the skin and for wounds out of which at least one third are herbal remedies. It has been estimated that in America 3-5\% of all hospitalized patients with spinal cord injuries suffer from ulcers. The cost of institutional care on the same is said to be US\$ 1000 per day while no such estimates are available for Indian institutions. The same demographic study has projected market expenditure of over US\$ 7 billion worldwide for provisions of wound healing properties. Both Traditional and Western systems of medicine for wound healing suffer from lack of resources and awareness. A need, therefore, arises for the advocacy and wider publication for relevant research to be pursued in this area. In broad terms, the relevant headings for consideration are utilization, safety and efficacy. Research on wound healing agents is, therefore, one of the developing areas in modern biomedical sciences ${ }^{1}$. 
Herbal remedies used in folk medicine provide an interesting and still largely unexplored source for the creation and development of potentially new drugs, which might help to overcome the growing problem of resistance and also the toxicity of the currently available commercial antibiotics. It is of great interest, therefore, to carry out screening of medicinal plants in order to validate their use in folk medicine ${ }^{2}$.

The present study envisages to select an appropriate local plant with wound healing ability based on its folklore claim and to formulate it as a conveniently usable formulation and to scientifically establish its anti-bacterial and wound healing activity. Passiflora foetida popularly known as passion flower in English belongs to the Passion genus and to the species foetida and passifloracea family. Ethnomedicinal uses of family Passifloraceae exhibits wound healing activity $^{3}$.

In this study we have made an attempt to formulate most complete herbal cream that contains various extracts of the leaves of Passiflora foetida which will satisfy almost all the mechanism to heal a wound effectively.

\section{METHODS AND MATERIAL}

\section{Collection of Plant Material}

Passiflora foetida (Passifloraceae) was collected from Arignar Anna Government Hospital Campus Arumbakkam, Chennai - 106. It was identified and authenticated by Mr. C.Arunachallam, Research officer (Botany), Captain Srinivasa Murti Research Institute of Ayurveda and Siddha Drug Development (CSMDRIA), Arumbakkam, Chennai - 106. Report No: 186/2010-2011. The leaves were dried, powdered and were taken up for the further studies.

\section{Preparation of Extracts}

\section{Hot percolation}

The dried, coarsely powdered Passiflora foetida leaf (700gm) was first extracted with Chloroform for 24h. Then the marc obtained was dried and extracted with Ethyl alcohol for $24 \mathrm{~h}$. The solvents were completely recovered from the collected successive extracts under reduced pressure by rotary vacuum evaporator. The concentrated extracts were dried on a water bath and preserved in a vacuum dessicator for further screening purpose.

\section{Formulation Aqueous Herbal Cream Bp ${ }^{4}$}

$$
\begin{aligned}
& \text { Preparation of emulsifying wax } \\
& \text { Cetostearyl alcohol - } 90 \mathrm{~g} \\
& \text { Sodium lauryl sulphate - } 10 \mathrm{~g} \\
& \text { Purified water - } 4 \mathrm{~mL}
\end{aligned}
$$

The cetostearyl alcohol was melted and heated to about 95oC. The sodium lauryl sulphate was dissolved in purified water and heated to $115 \mathrm{oC}$. The two ingredients were mixed

Together, stirred vigorously until frothing ceases and the product is translucent. Cool quickly.

$$
\begin{aligned}
& \text { Preparation of emulsifying ointment } \\
& \text { Emulsifying wax - } 30 \mathrm{~g} \\
& \text { White soft paraffin - } 50 \mathrm{~g} \\
& \text { Liquid paraffin - 20g }
\end{aligned}
$$

All the ingredient were melted together and stirred until cold.

$$
\begin{aligned}
& \text { Preparation of aqueous cream } \\
& \text { Emulsifying ointment - } 30 \mathrm{~g} \\
& \text { P-chlorometacresol - } 0.001 \mathrm{~g} \\
& \text { Purified water q.s to (heated to } 60^{\circ} \mathrm{C} \text { ) - } 100 \mathrm{~g}
\end{aligned}
$$


The emulsifying ointment and P-chlorometacresol were melted and heated to $60^{\circ} \mathrm{C}$.Sufficient water was heated to $60 \mathrm{oC}$. The above ingredient was added and stirred gently until cool and add sufficient purified water to produce $100 \mathrm{gm}$.

Preparation of herbal cream using chloroform extract

Aqueous cream - $95 \mathrm{~g}$

Chloroform extract $-5 \mathrm{~g}$

The above ingredients were mixed together and stirred.

Preparation of herbal cream using ethanol extract

Aqeous cream - $95 \mathrm{~g}$

Ethanol extract $-5 \mathrm{~g}$

The above ingredients were mixed together and stirred.

\section{Evaluation of Cream ${ }^{5-7}$}

Accelerated stability testing of prepared formulations was conducted for herbal cream of Chloroform and ethanol extracts at $40 \pm 1^{\circ} \mathrm{C} \& 70 \pm 5 \% \mathrm{RH}$ for 90 days. The formulations were analysed initial and on 30, 60 and 90 days for the following parameters. Type of emulsion (Dye method), $\mathrm{pH}$, Ash, Homogeneity, Appearance, Rubout, After feel, Type of smear, Removal, Draize skin sensitivity test, Estimation of total phenolic compounds, Estimation of total flavonoid.

\section{WOUND HEALING ACTIVITY}

\section{Acute toxicity study ${ }^{8}$}

Earlier studies have reported that $P$. foetida extract did not cause any acute toxic effects and mortality in mice. It was reported that LD50 should be more than $40 \mathrm{~g} / \mathrm{kg}$, which could be regarded as a practically non-toxic compound.

\section{Experimental Animals}

Wistar rats $(175-200 g)$ were used for the study. They were maintained at the Experimental Animal's Laboratory Madras Medical College, chennai .They were housed in polypropylene cages under controlled lab conditions and fed with standard pellet diet and water ad libitum clearance from the Institutional Animal Ethical Committee was obtained for carrying out the experiment (21/243-CPCSEA-10/08/2011).

\section{Screening of wound healing activity9,10}

Wound healing activity was done by two models

1. Excision wound model

2. Incision wound model

\section{Excision wound model}

The animals are divided into 4 groups and 6 animals in each group.

Group I - Cream base

Group II - Standard (5 \% w/w Povidone iodine oinment)

Group III - Test $[5 \%$ w/w Herbal Cream (CHCl3 Extract)]

Group IV - Test $[5 \%$ w/w Herbal Cream (EtOH Extract)

Animals are anesthetized prior to and during creation of the wounds, with $1 \mathrm{ml}$ of intravenous ketamine hydrochloride $(10 \mathrm{mg} / \mathrm{kg})$. The dorsal fur of the animals was removed with depilatory cream and the anticipated area of the wound to be created was outlined on the back of the animals.An impression was made on the dorsal thoracic region $1 \mathrm{~cm}$ away from vertebral column and $5 \mathrm{~cm}$ away from ear on the anaesthetized rat with $5 \mathrm{~mm}$ biopsy punch. A full thickness of the excision wound of circular area was created along the markings using toothed forceps, scalpel and pointed scissors. Haemostasis was achieved by blotting the wound with cotton swab soaked in normal saline. The entire wound was left open. All surgical procedures were performed under aseptic conditions. $0.5 \mathrm{~g}$ of control, test and standard 
drug was applied once daily. The wound closure rate was assessed by tracing the wound on days $1,4,6,8$, 11,14 and 16 post wounding days using transparent paper and a permanent marker. The wound areas recorded were measured using graph paper. Changes in wound area were calculated, gives an indication of the rate of wound contraction. ${ }^{11}$

The percentage of wound healing was calculated by the formula. \% Wound Closure =

(Original wound size - size of the wound on nth day/Original wound size) X 100

Statistical analysis was done using ANOVA followed by Bonferroni multiple comparison test

\section{Linear incision wound model}

The animals were divided into 4 groups with 6 animals in each group.

Group I - Cream base

Group II - Standard (5 \% w/w Povidone iodine oinment)

Group III - Test $[5 \%$ w/w Herbal Cream $(\mathrm{CHCl} 3$ Extract)]

Group IV - Test [5 \% w/w Herbal Cream (EtOH Extract)]

The rats were anaesthetized prior to and during creation of the wounds, with $1 \mathrm{ml}$ of Intravenous ketamine hydrochloride $(10 \mathrm{mg} / \mathrm{kg})$. The dorsal fur of the animals was removed with depilatory cream. A longitudinal para-vertebral incision of $6 \mathrm{~cm}$ long was made through the skin and cutaneous tissue on the back. After the incision, the parted skin was sutured $1 \mathrm{~cm}$ apart using a surgical thread and curved needle. The wounds were left undressed. The control, test and standard drug was applied once daily. The sutures were removed on 8th post wound day and continued the application of the cream. Animals were sacrificed on the 10th day. The portion of the skin where the wound was created was removed after sacrificing the animal. One portion of the skin is to be used for evaluation of tensile strength and the other portion will be taken for Histo-pathological evaluation and Hydroxyl Proline estimation. ${ }^{12}$

\section{RESULTS AND DISCUSSION}

\section{Evaluation of Cream}

The evaluation of cream indicates that the cream made from Chloroform extract was brown in colour, whereas the cream made from the ethanol extract was yellow in colour.

The $\mathrm{pH}$ indicates that both the creams were almost neutral.

The cream was homogenous, were easily spread able the type of smear after application of cream was non greasy and the after feel was emollient.

The cream was easily removable by washing and the dye test indicates that the emulsion is an $\mathrm{o} / \mathrm{w}$ emulsion.

The Draize skin sensitivity showed that there was no sign of irritation such as redness or erythema indicating that both the cream was non-irritant. The results are given in Table 1 .

\section{Estimation of Total Polyphenol Content ${ }^{13}$}

The total poly phenol content was estimated by Folin Ciocalteu method. The poly phenol content was expressed as Gallic acid equivalent in $\mu \mathrm{g} / 100 \mathrm{gm}$. The Gallic acid caliberation curve was prepared by using various concentrations of 50,100,150,200,250 $\mu \mathrm{g} / 100$ gm Gallic acid. The curve was given in fig 1.The total poly phenol content in the cream with chloroform extract was found to be $3.34 \%$.and it was higher in the cream containing ethanol extract the quantity was $4.45 \%$ the results are given in Table 2 .

\section{Estimation of Total Flavone and Flavonol Content}

The total flavonoid content was estimated by calorimetry method. The poly phenol content was 
expressed as quercetin equivalent in $\mu \mathrm{g} / 100 \mathrm{gm}$. the quercetin calibration curve was prepared by using various concentration of 20,40,60,80,100 $\mu \mathrm{g} / 100 \mathrm{gm}$ gallic acid. The curve was given in fig 2.The total flavonoid content in the cream with chloroform extract was found to be $0.17 \%$ and it was higher in the cream containing ethanol extract the quantity was $0.35 \%$. The results are given in Table 3 .

\section{Accelerated Stability Testing}

The evaluation report of the creams subjected to accelerated stability studies are given in Table 4 and 5 . There was no change in colour, homogeneity and spreadibility with very minimum alteration in $\mathrm{pH}$ at all test periods. The total polyphenol content and flavone and flavonoid content also did not show major alteration. Achieved results suggest that the developed creams with chloroform and ethanol extract of Passiflora foetida Linn, extract possess the good quality emulsion system warranting the stability of poly phenol and flavone content. Products formulated maintained physical stability in accelerated condition. This indicates that the creams are stable.

\section{WOUND HEALING ACTIVITY}

\section{Excision wound healing}

This model evaluates wound healing activity by estimating the wound closure tendency. The wound size was evaluated on $0,4,6,8,12$ th days. The results are given in Table 6 .

The initial size on day 0 of all the wounds was almost the same ranging between 51 and $53 \mathrm{~mm} 2$. In the vehicle control group where only cream base is used, the wound size decreased to $4.5 \mathrm{~mm} 2$ on day 12 . The standard drug Povidone Iodine cream produced a significant reduction in wound size on all tested animals and by the 8 th day wound size had reduced to $3.6 \mathrm{~mm} 2$ and the wound was totally closed on day 12. In the case of cream prepared with chloroform extract an almost similar activity as that of standard group was seen. The wound showed $93.6 \%$ closure on day 8 and there was no wound on day 12 .

The cream prepared with ethanol extract showed excellent activity there was significant wound healing on all days. There was $91.6 \%$ wound closure on day 6 and the wound was totally healed on day 8 . The results graphically represented in Figure 1\&2.

\section{Incision Wound Model (Figure 3)}

The wound healing activity was determined by determination of tensile strength and estimation of hydroxy proline content of the wounds on the 10 th post wound day.

The tensile strength was lowest in the control group which are only treated with the cream base. In the case of Povidone Iodine treated treated animals, the tensile strength showed a higher value of $506.1 \mathrm{~g}$. In the case of chloroform extract cream the tensile strength showed similar activity as that of standard cream. The cream prepared with the ethanol extract the tensile strength increased considerbly indicating very good wound healing potential. Table 7 .

This was also confirmed by the estimation of the hydroxy proline content of the healed skin. Hydroxy proline content was higher than that of control group values with the usage of standard Povidone Iodine and cream prepared with chloroform extract. Table 7. In the case of cream prepared with ethanolic extract, the level of hydroxy proline was the maximum indicating a high level of collagen synthesis and healing.

\section{Histopathological Studies}

The standard drug Povidone Iodine cream produces more collagen formation on healed skin on day 12 . The cream prepared with chloroform extract showed similar collagen formation as that of standard drug. The cream prepared with ethanol extract showed more collagen formation than Povidone Iodine and 
chloroform extract cream. The results are given in

Figure 4.

Table 1: Evaluation of Aqueous Herbal Creams

\begin{tabular}{|c|c|c|c|c|c|c|c|c|c|c|}
\hline Formulation & Colour & $\mathbf{P}^{\mathbf{H}}$ & Homogenity & $\begin{array}{c}\text { Spreadab } \\
\text { ility }\end{array}$ & $\begin{array}{c}\text { Type } \\
\text { of } \\
\text { smear }\end{array}$ & $\begin{array}{c}\text { After } \\
\text { feel }\end{array}$ & Removal & $\begin{array}{c}\text { Type of } \\
\text { emulsi } \\
\text { on }\end{array}$ & Ash & skin \\
test
\end{tabular}

Table 2 : Total polyphenol content of Aqueous Herbal Creams

\begin{tabular}{|c|c|c|}
\hline Formulation & $\begin{array}{c}\text { Absorbanc } \\
\text { e }\end{array}$ & $\begin{array}{c}\text { Total polyphenol } \\
\text { content }\end{array}$ \\
in \% as GAE \\
\hline $\begin{array}{c}\mathrm{CHCl}_{3} \text { extract } \\
\text { cream }\end{array}$ & 0.026 & 3.34 \\
\hline $\begin{array}{c}\text { EtOH extract } \\
\text { cream }\end{array}$ & 0.038 & 4.45 \\
\hline
\end{tabular}

Table 3: Total flavone and flavonol content of Aqueous Herbal Creams

\begin{tabular}{|c|c|c|}
\hline Formulation & $\begin{array}{l}\text { Absorban } \\
\text { ce }\end{array}$ & $\begin{array}{c}\text { Total flavone and flavonol } \\
\text { content } \\
\text { In \% as QE }\end{array}$ \\
\hline $\begin{array}{c}\mathrm{CHCl}_{3} \text { extract } \\
\text { cream }\end{array}$ & 0.04 & 0.17 \\
\hline $\begin{array}{c}\text { EtOH extract } \\
\text { cream }\end{array}$ & 0.06 & 0.35 \\
\hline
\end{tabular}

Table 4 : Evaluation of aqueous herbal cream in accelerated conditions

\begin{tabular}{|c|c|c|c|c|c|}
\hline Days & Formulation & Colour & pH & Homogenity & Spreadability \\
\hline Initial & \multirow{4}{*}{$\mathrm{CHCl}_{3}$ extract cream } & \multirow{4}{*}{ Brown } & 7.2 & \multirow{4}{*}{ Good } & \multirow{4}{*}{ Good } \\
\hline 30 & & & 7.2 & & \\
\hline 60 & & & 7.1 & & \\
\hline 90 & & & 7.1 & & \\
\hline Initial & \multirow{4}{*}{ Ethanol extract cream } & \multirow{4}{*}{ Yellow } & 7.1 & \multirow{4}{*}{ Good } & \multirow{4}{*}{ Good } \\
\hline 30 & & & 7.1 & & \\
\hline 60 & & & 6.9 & & \\
\hline 90 & & & 6.9 & & \\
\hline
\end{tabular}

Table 5 : Total polyphenol and Total flavone and flavonol content of aqueous herbal cream in accelerated conditions

\begin{tabular}{|c|c|c|c|}
\hline Days & Formulation & $\begin{array}{c}\text { Total polyphenol } \\
\text { content } \\
\text { In } \% \text { as GAE }\end{array}$ & $\begin{array}{c}\text { Total flavone and } \\
\text { flavonol content } \\
\text { In \% as QE }\end{array}$ \\
\hline Initial & \multirow{4}{*}{$\mathrm{CHCl}_{3}$ extract cream } & 3.34 & 0.17 \\
\hline 30 & & 3.25 & 0.17 \\
\hline 60 & & 3.25 & 0.17 \\
\hline 90 & & 3.06 & 0.17 \\
\hline Initial & \multirow{4}{*}{ Ethanol extract cream } & 4.45 & 0.35 \\
\hline 30 & & 4.45 & 0.35 \\
\hline 60 & & 4.17 & 0.35 \\
\hline 90 & & 4.08 & 0.35 \\
\hline
\end{tabular}


Table 6 : Wound Closure in Excision Wounds

\begin{tabular}{|c|c|c|c|c|c|}
\hline Groups & $\begin{array}{l}0 \text { day } \\
\text { mm }^{2}\end{array}$ & $\begin{array}{c}4^{\text {th }} \text { day } \\
\mathrm{mm}^{2}\end{array}$ & $\begin{array}{c}6^{\text {th }} \text { day } \\
\mathrm{mm}^{2}\end{array}$ & $\begin{array}{c}8^{\text {th }} \text { day } \\
\mathrm{mm}^{2}\end{array}$ & $\begin{array}{c}12^{\text {th }} \text { day } \\
\mathrm{mm}^{2}\end{array}$ \\
\hline Control & $52.83 \pm 1.28$ & $\begin{array}{c}36.17^{*} \pm \\
1.32(39.7)\end{array}$ & $\begin{array}{c}22.5^{*} \pm \\
1.87(75.0)\end{array}$ & $\begin{array}{c}13.16^{*} \pm \\
0.65(75.0)\end{array}$ & $\begin{array}{c}4.5^{*} \pm \\
0.22(93.7)\end{array}$ \\
\hline $\begin{array}{l}\text { Std (Povidone } \\
\text { Iodine) }\end{array}$ & $52.16 \pm 0.63$ & $\begin{array}{c}21.00^{*} \pm \\
0.63(63.3)\end{array}$ & $\begin{array}{c}21.00^{*} \pm \\
0.89(63.3)\end{array}$ & $\begin{array}{c}3.6^{*} \pm \\
0.33(93.0)\end{array}$ & ${ }^{*}(100)$ \\
\hline $\begin{array}{c}\text { EtOH Extract } \\
\text { Cream }\end{array}$ & $51.83 \pm 0.79$ & $\begin{array}{c}13.33^{*} \pm \\
0.42(91.6)\end{array}$ & $\begin{array}{c}3.66^{*} \pm \\
0.42(91.6)\end{array}$ & $0^{*}(100)$ & $0^{*}(100)$ \\
\hline $\begin{array}{c}\mathrm{CHCl}_{3} \text { Extract } \\
\text { Cream }\end{array}$ & $51.67 \pm 0.98$ & $\begin{array}{c}24.33^{*} \pm \\
1.66(73.2)\end{array}$ & $\begin{array}{c}* \\
12.33 \pm \\
0.80(73.2)\end{array}$ & $\begin{array}{c}* \\
4.66 \pm \\
0.21(100)\end{array}$ & $0^{*}(100)$ \\
\hline
\end{tabular}

Values are expressed as mean \pm S.E.M $(n=6) . * P<0.0001$ when compare to zero day.

The values in brackets indicate the $\%$ wound closure

Table 7 : Hydroxyproline content and Tensile Strength of healed skin in linear incision model

\begin{tabular}{|c|c|c|}
\hline Groups & $\begin{array}{c}\text { Tensile Strength } \\
(\mathbf{g})\end{array}$ & $\begin{array}{c}\text { Hydroxyproline } \\
\text { mg/g tissue }\end{array}$ \\
\hline Control & $404.7 \pm 6.1$ & $37 \pm 3.1$ \\
\hline Std (Povidone Iodine) & $506.1 \pm 3.2$ & $61 \pm 2.2$ \\
\hline $\mathrm{CHCl}_{3}$ Extract Cream & $504.4 \pm 5.3$ & $65 \pm 3.6$ \\
\hline EtOH Extract Cream & $649.7 \pm 23.1$ & $73 \pm 4.0$ \\
\hline
\end{tabular}
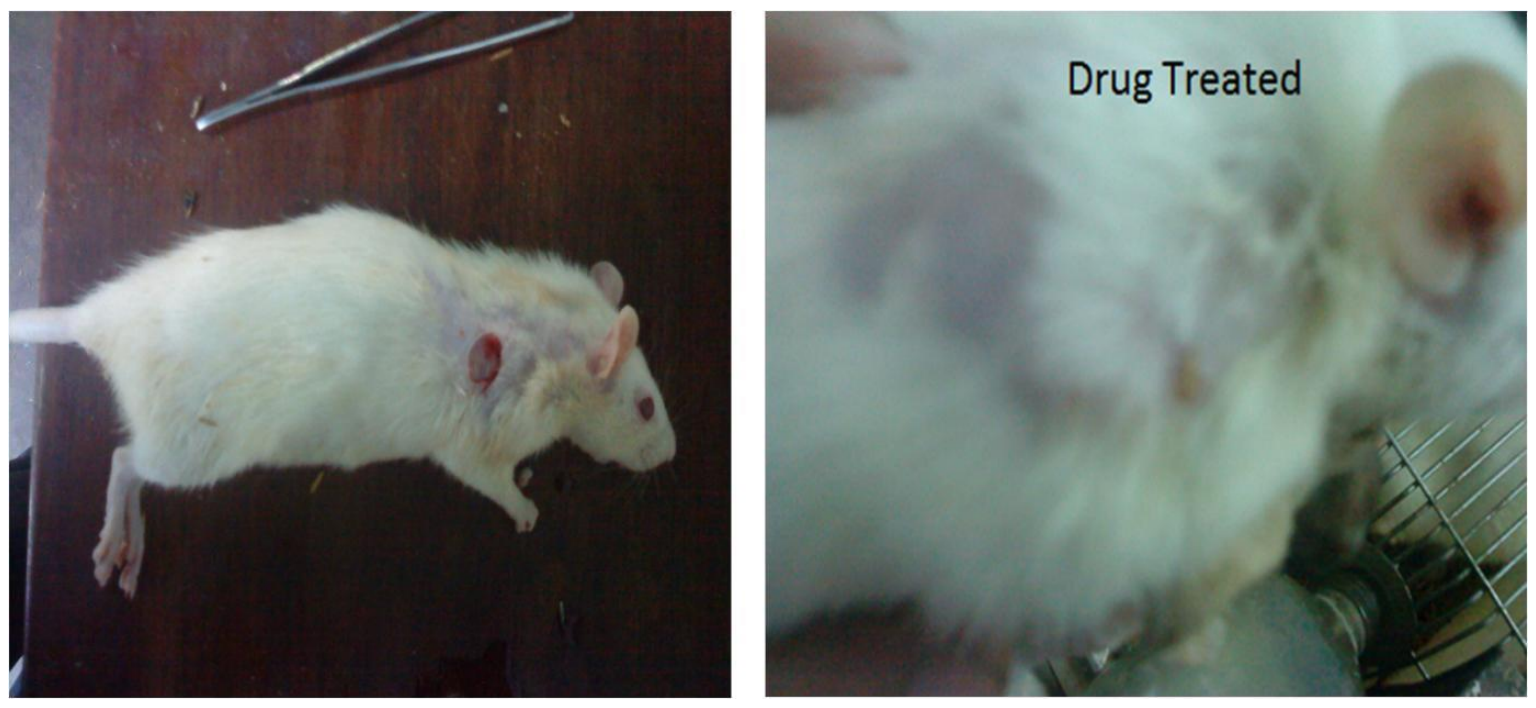

Figure 1: Excision Wound Model 


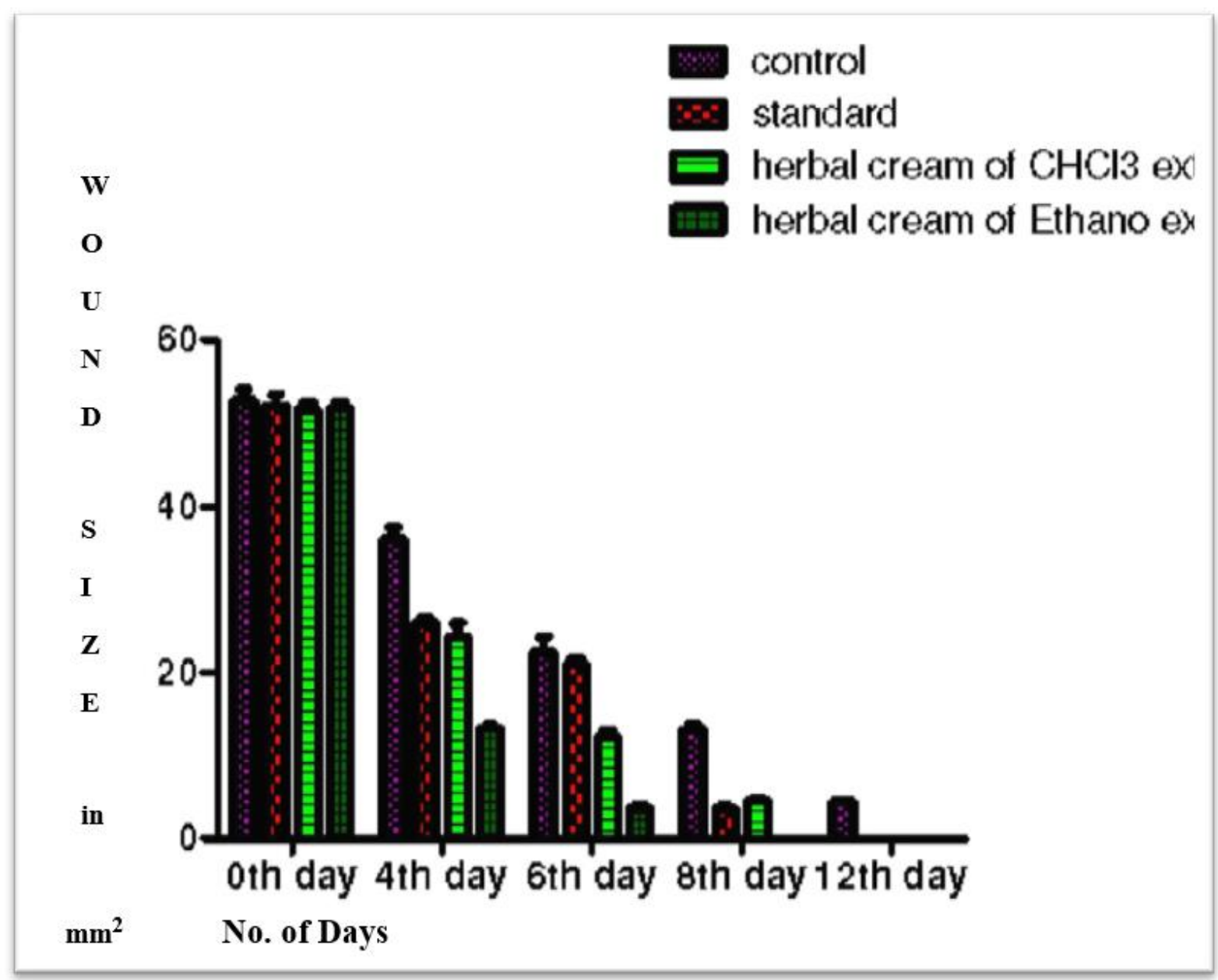

Figure 2 : Wound Healing Effect
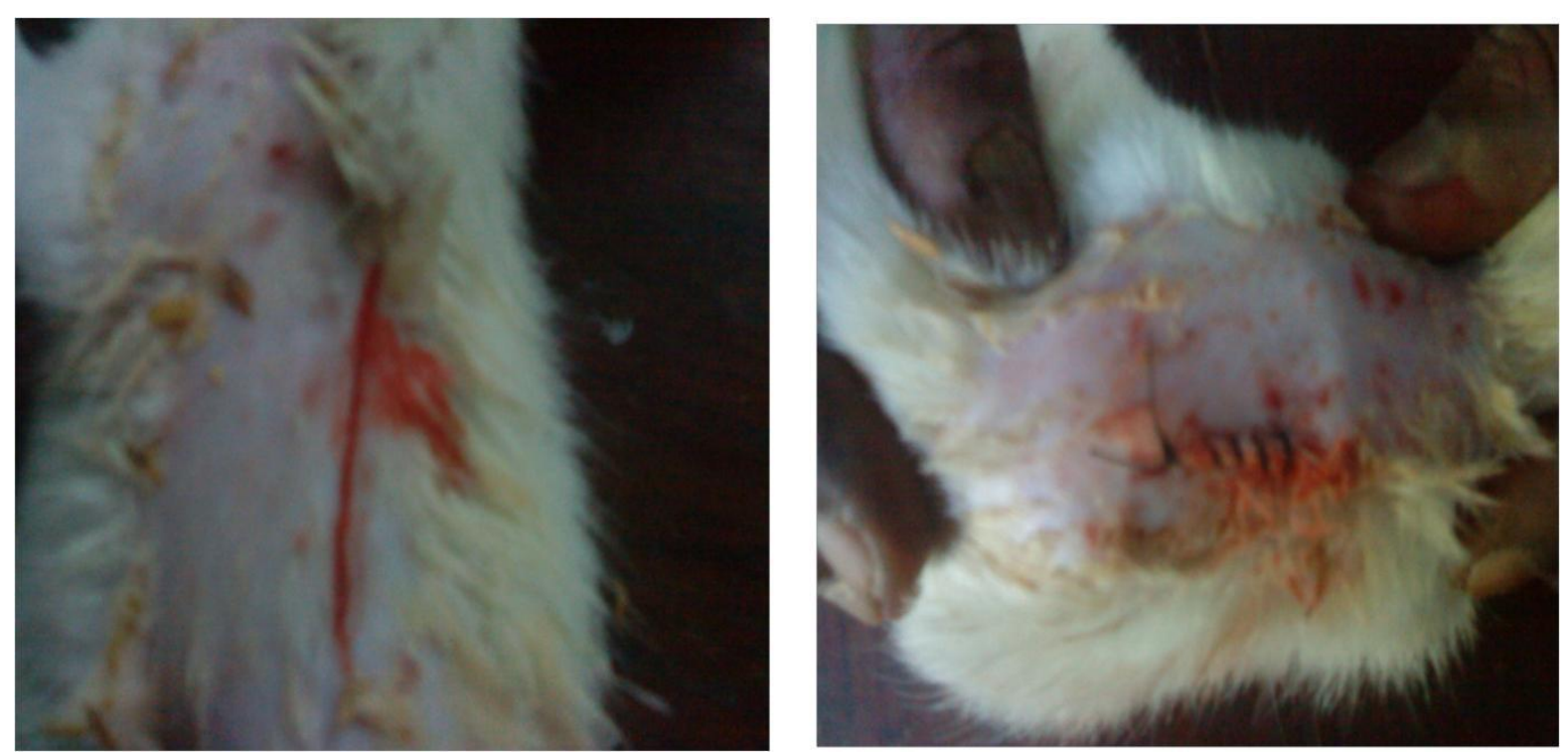

Figure 3 : Linear incision wound model 
Cream Base

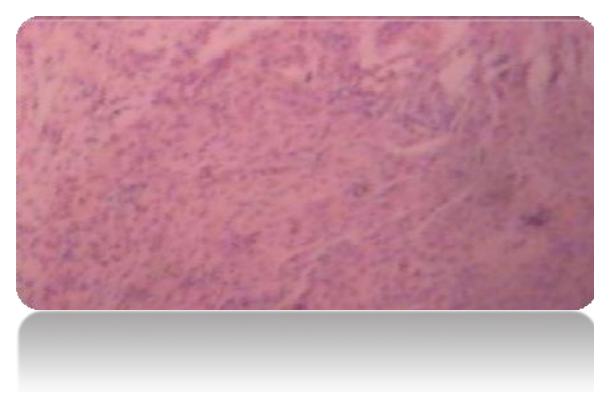

Chloroform Extract Cream

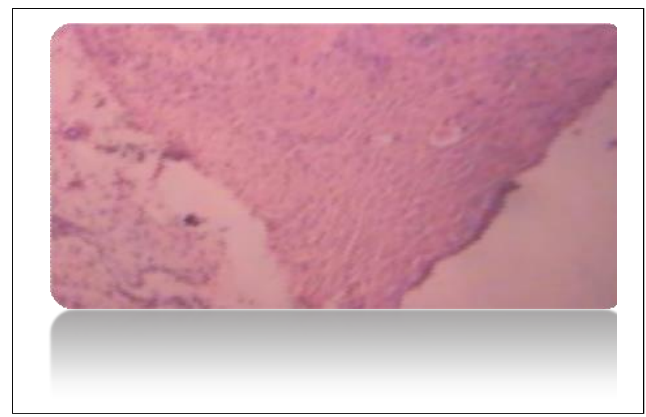

$5 \%$ Povidone Iodine

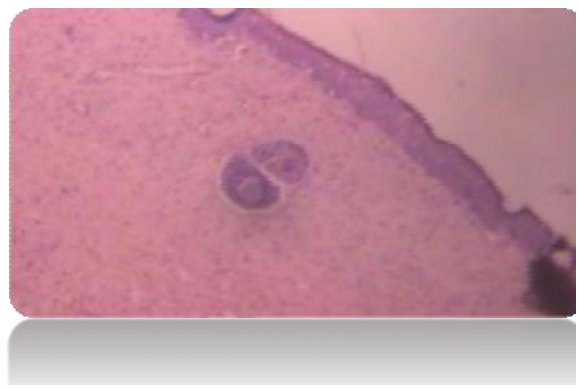

Ethanol Extract Cream

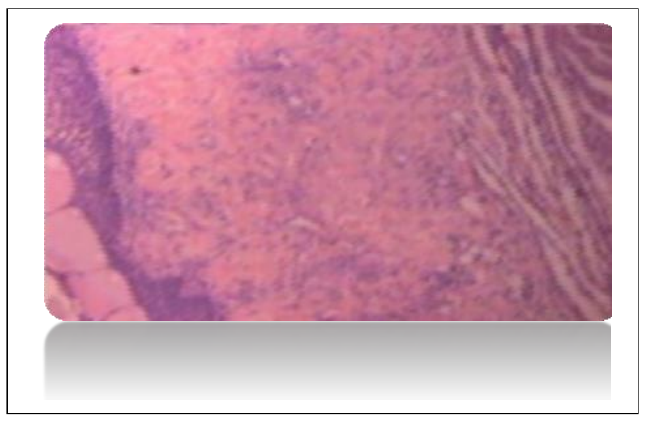

Figure 4 : Histology of rat skin on incision wound model on day 12

\section{IV.CONCLUSION}

Ethnomedical use of family Passifloraceae is the treatment of wounds. Passiflora foetida Linn is a which belong to this family. Different parts of these plants have been claimed to be effective in a wide spectrum of diseases. The literature survey indicates that no scientific has been reported on wound healing potential of Passiflora foetida Linn.,The aim of the present investigations was, therefore, proposed to formulate an aqueous cream from the suitable extract of leaves of Passiflora foetida and to test its wound healing activity. The two extracts were formulated as an aqueous cream in a concentration of $5 \% \mathrm{w} / \mathrm{w}$. The creams were evaluated and were also subjected to accelerated stability studies. The cream showed favourable properties and accelerated stability studies also showed that there were no profound changes in the various parameters.
Both the creams were then pharmacologically evaluated for their wound healing property using excision and incision wound models. The creams prepared with both chloroform and ethanol extract showed wound healing ability which was comparable to the standard Povidone Iodine ointment. The activity of ethanol extract cream was seen to be superior to standard ointment.

The present study confirms the wound healing property of Passiflora foetida Linn., leaves especially the ethanol extract. Future studies could establish better parameters for standardisation, the nature of the isolated compound could be confirmed. The creams efficacy of the cream could also be evaluated for clinical settings. 


\section{REFERENCES}

[1]. Kumar B, Vjaykumar M, Govindarajan R, Pushpangadan P. Ethano pharmacological approaches to wound healing: exploring medicinal plants of India. J Ethnopharmacol. 2007; 114: 103-113.

[2]. Oskay M, Sari D. Antimicrobial screening of some Turkish medicinal plants. Pharm Biol. 2007; 45(3): 176-181

[3]. The biology of vines - by Francis E.putz .Pg.No: 458.

[4]. British Pharmacopoeia. 2007; 3: 2389.

[5]. Sahu alakh N, Jha S and Dubey S D. Formulation \& evaluation of curcuminoid based herbal face cream. Indo-Global Journal of Pharmaceutical Sciences. 2011; 1(1): 77-84.

[6]. Bernatoniene et al. Topical application of Calendula officinalis (L.): Formulation and evaluation of hydrophilic cream with antioxidant activity. Journal of Medicinal Plants Research. 2011; 5(6) : 868-877

[7]. ICH guideline Q1A (R2) Stability Testing of new Drug Substances and Products.

[8]. Frank C.Lu. Basic toxicology. Consulting Toxicologist Miami, Florida Hemisphere Publishing Corporation, New York. 1985: 104.

[9]. Keerthana. K et al., Study on wound healing properties of a Polyherbal ointment. Journal of Pharmacy Research. 2011; 4(6):1726-1728.

[10]. Dash GK And Narasimhamurthy P. Wound healing effects of Ageratum conyzoides linn.. International Journal of Pharma and Bio Sciences 2011; 2(2): 369-383.

[11]. Jagetia GC, Rajanikant GK. Role of curcumin, a naturally occurring phenolic compound of turmeric in accelerating the repair of excision wound in mice whole-body exposed to various doses of $\gamma$-radiation. J Surg Res 2004; 120:127-138
[12]. Edwards and W.D O Brien JR. modified assay for determination of hydroxyl proline in a tissue hydrolyzate clinica chemical Acta .104: 161-167

[13]. Jagetia GC, Rajanikant GK. Role of cucumin, a naturally occurring phenolic compound of turmeric in accelerating the repair of excision wound in mice whole-body exposed to various doses of $\gamma$-radiation. J Surg Res. 2004; 120:127

Cite this article as : Akila E, C. Geetha Priya, "Formulation and Evaluation of Wound Healing Effect of Aqueous Herbal Cream Containing Various Extracts of Passiflora foetida Linn., Leaves", International Journal of Scientific Research in Science and Technology (IJSRST), Online ISSN : 2395-602X, Print ISSN : 2395-6011, Volume 6 Issue 1, pp. 490-499, January-February 2019.

Available at doi :

https://doi.org/10.32628/IJSRST196171

Journal URL : http://ijsrst.com/IJSRST196171 